\title{
Corporate Rescue as Sustainable Mechanism for Strengthening Companies in Nigeria?
}

\author{
Olusegun O. Onakoya, LL.B (Hons) BL, LLM, PhD. \\ Senior Lecturer, Department of Commercial and Industrial Law, Faculty of Law, \\ University of Ibadan, Ibadan. Nigeria
}

\begin{abstract}
Company, upon its incorporation becomes a legal personality or "legal abstraction" with powers to act for it with respect to formation of contract, right to sue and be sued (a juristic personality), right to own properties (real properties and chattels) among others. However, the characteristic that distinguishes companies from other forms of business organization is that aside from the companies being different from its members, it has the capacity for perpetual existence. The exit of its members will not necessarily 'terminates' the life of the company, since at best such member reserves the right of transfer his/her shares. This legal attribute of a company has however not been true of many companies that found themselves in the "murky waters" of bankruptcy and may therefore have to go through the winding up process, which usually ultimately "terminates" the life of such companies. However, with the dwindling fortunes of companies in the $21^{\text {st }}$ century, and many having to wind up' business activities as a result of insolvency, it becomes imperative that attempts be made to rescue the company from 'dying' rather than wait to give same 'decent burial' by way of liquidation and winding up process. This new concept is referred to as "Corporate Rescue"
\end{abstract}

Keywords: Insolvency, Liquidation and Receivership, Corporate Rescue, Law Reform.

DOI: $10.7176 / \mathrm{JLPG} / 118-07$

Publication date: February $28^{\text {th }} 2022$

\section{INTRODUCTION}

Companies, no doubt play pivotal role in the economic growth of nations, however at some point during the existence of a company, it is possible that such company is unable to settle its debts, having seemingly exhausted all the available means. In such a circumstance, the liabilities of the company may even exceed its assets. This is usually refers to as insolvency.

At a time like this in the life of a company, the creditors and other stakeholders will have to appraise the options open to them to satisfy their respective interest and pursue same. The commonest of this option in Nigeria is to commence winding-up process of the 'ailing' company. However, in the recent time, some other options are now being considered with a view to give "life" to the 'ailing' company, make it 'healthy' again and without prejudice to the interest of the creditors and other stakeholders.

In Nigeria till date, the speed at which the liquidators commence work when appointed cannot be overemphasized and the excitement and enthusiasm usually demonstrated while carrying out the assigned responsibilities leave much to be desired, as they left no one in doubt of their eagerness to bring to an end the existence of such insolvent companies.

\subsection{Insolvency Law}

Insolvency law, practice and process in Nigeria determines whether a financially weak corporate entity will survive the crisis or not. Insolvency is defined as a condition of being unable to pay debts as they fall due or in the usual course of business. ${ }^{1}$ It may also mean failure to satisfy or fulfill financial obligations to the creditors.

The words depicting Insolvency has its root in Latin "not solvetem" which means 'not paying'. The words 'bankruptcy' and insolvency are usually employed interchangeably, and rightly so, within the context they are used. It is imperative to note that there is no Insolvency Act in Nigeria. The major source of corporate insolvency law in Nigeria is the Companies and Allied Matters Act (CAMA) 2020 which is a significant improvement on CAMA 2004.

Corporate insolvency has to do with the companies or corporations which are unable to pay their debts. Two (2) major categories of insolvency are recognized, namely: (i) Cash flow insolvency and (ii) Balance sheet insolvency. The distinction between the two (2) cannot be over-emphasized.

Cash flow insolvency is a temporary cash crisis and a situation where a corporate personality can no longer meet the debt obligations on time as they fall due. Balance sheet insolvency, on the other hand will arise where companies liability exceed the assets of the company. This type of insolvency establishes a typical case of liquidation.

Chapter 26 of CAMA 2020 provides comprehensively for corporate insolvency practice and procedure in

\footnotetext{
${ }^{1}$ Black’s law Dictionary, 1990. Eight ed. St. Paul MN. West Publishing Company: 811
} 
Nigeria, particularly as to the eligibility of person or group of persons to act as insolvency practitioners. Insolvency law has been defined as a collection of laws and processes for the resolution of the financial affairs of companies in financial difficulties. ${ }^{1}$ In Nigeria, the terms 'insolvency' and 'bankruptcy' are understood and used interchangeably to refer to both individual and company insolvencies.

Technically, individuals become bankrupt and go into 'bankruptcy' as provided for under the Bankruptcy Act, ${ }^{2}$ and companies go through winding-up process as provided for under CAMA 2020.

\subsection{Winding up}

A company is regarded by law to be an artificial person. However, much unlike a natural person that has life expectancy and may become deceased at any time, upon the incorporation of a company, it becomes a 'legal abstraction' with the attribute of perpetual succession.

However in the practical sense, the company's attribute of perpetual succession is neither absolute nor without limitation, the law therefore provides for a procedure of terminating the life of a company and the factors or circumstances that may be responsible for such. The procedure for the aforesaid exercise is referred to as liquidation and involves the carrying out of certain functions by officers specially appointed for the purpose. ${ }^{3}$

Interestingly, both solvent and insolvent companies may be wound-up. In the winding up or liquidation, the company gives up its business, sells off its assets, pays its debts (or, if it is insolvent, does so to the extent that its funds allow) and distributes whatever surplus or excess that remains amongst its members or otherwise as its constitution may provide ${ }^{4}$.

The conduct of the winding up process is placed in the hands of a liquidator; and on his appointment the directors' power to manage the business of the company ceases.

The major functions of a liquidator include but not limited to the following:

i. To settle the list of the contributories;

ii. To collect the company assets;

iii. To discharge the company's liabilities to its creditors;

iv. To redistribute the surplus (if any) to the contributories according to the rights attaching to their shares of the company's capital. ${ }^{5}$

\subsection{Modes of Winding up}

Section 564 CAMA 2020 provides that the winding up of a company may be affected

a) By the court;

b) Voluntarily; or (c) Subject to the supervision of the court.

\subsubsection{Compulsory Winding up by the Court.}

Winding up by the court is otherwise referred to as compulsory winding up. Some individuals or group of persons may petition to the court for the winding up of a company on certain grounds.

By virtue of section 573 (1) CAMA 2020, some persons are eligible to present petition to the court for winding up. Such persons are:

1. the company or a director;

2. a creditor, including a contingent or prospective creditor of the company;

3. the official receiver;

4. a contributory;

5. a trustee in bankruptcy to, a personal representative of, a creditor or contributory;

6. the Commission under section 366 of this Act;

7. a receiver, if authorized by the instrument under which he was appointed; or

8 . by all or any of those parties, together or separately.

The court that has jurisdiction to wind-up a company or preside over issues bothering on companies' winding up process is the federal high court within whose area of jurisdiction the registered office or head office of the company is situated ${ }^{6}$.

\subsubsection{Grounds for Court-Ordered Winding Up}

Quite unlike CAMA 2004 LFN which listed five (5) grounds upon which petition may be made to court for winding-up of a company, ${ }^{7}$ the current CAMA provides for six (6) different circumstances that may give rise to

\footnotetext{
${ }^{1}$ Fletcher, I.\& Crabb, L. (1990) The law of insolvency, 4th edition, London, Sweet \& Maxwell: 33.

${ }^{2}$ See generally Bankruptcy Act, Cap B2 LFN 2004

${ }^{3}$ Kemela, O.\& Austyne, I. O; (2004). Procedural issues in company liquidation and receivership. Paper presented at the 24th advanced course in practice and procedure at the Nigeria Institute of Advance Legal Studies, Lagos, Nigeria on the 25th October, 2004

${ }^{4}$ Sealy L; \& Worthington, S; (2010). Sealy's cases and materials in company Law, 9th edition. Oxford. Oxford University Press: 744

${ }^{5}$ Keenan, D.1987. Smith and Keenan's Company Law Seventh edition, London. Pitman publishing: 400

${ }^{6}$ See generally section 570 CAMA 2020

${ }^{7}$ Akomolede, I. (2008). Fundamentals of Nigerian company law, Lagos, Niyak Print and Publications: 138. See generally the provisions of
} 
petition being made to court for winding up order. The grounds are listed below:

a) the company has by special resolution resolved that the company be wind- up by the court;

b) default is made in delivering the statutory report to the Commission or in holding the statutory meeting;

c) the number of members is reduced below two in the case of companies with more than one shareholder;

d) the company is unable to pay its debts;

e) the condition precedent to the operation of the company has ceased to exist; or

f) the court is of opinion that it is just and equitable that the company should be wind up.

Paragraph (e) above as newly introduced into CAMA will go a long way to serve a practical value in a bid to further regulate the company's management and corporate governance.

The words 'inability to pay its debts' in section 571(d) above is comprehensively defined in section 572 (a)(c) as follows:

\section{A company is deemed to be unable to pay its debts if-}

a. a creditor, by assignment or otherwise, to whom the company is indebted in a sum exceeding \#200,000 then due, has served on the company, by leaving it at its registered office or head office, a demand under his hand requiring the company to pay the sum due or to secure or compound for it to the reasonable satisfaction of the creditor;

b. execution or other process issued on judgment, act or order of any court in favour of a creditor of the company is returned unsatisfied in whole or in part; or

c. the court, after taking into account any contingent or prospective liability of the company, is satisfied that the company is unable to pay its debts.

\subsubsection{Voluntary Winding up of a Company}

This is defined as a winding up of a company initiated by a special or extraordinary resolution of the company rather than by a petition to the court. ${ }^{1}$

In Nigeria, any company may be wound up voluntarily-

a) when the period, if any, fixed for the duration of the company by the articles expires, or the event, if any, occurs on occurrence of which the articles provided that company is to be dissolved and the company in general meeting has passed a resolution requiring the company to be wound up voluntarily;

b) if the company resolves by special resolution that the company be wound up. ${ }^{2}$

It is important to note that members' voluntary winding up is only possible when the company is solvent. Generally, before the commencement of the member's voluntary winding up, the directors must make a written declaration that they have inquired into the affairs of the company and are of the opinion that the company would be able to pay the creditors in full within one year after the commencement of the winding-up proceeding, otherwise members' voluntary winding up will not be possible and may later be converted to creditors' voluntary winding up. ${ }^{3}$

The procedure for voluntary winding up is clearly spelt out in CAMA $2020^{4}$ there is no doubt that the provision relating to declaration of solvency by the directors of the company being sought to be wound up is primarily to protect the interests of the company's creditors.

\subsubsection{Creditors' Voluntary Winding Up}

A creditors' voluntary winding up occurs where the directors are not able to make a declaration of solvency. The directors are under the obligation to call the meeting of all the company's creditors and at such meeting laid bare the statement of the company's affairs together with the list of their claims.

This action of the directors will pave way for the appointment of a liquidator, after which all the powers of the directors shall cease forthwith. ${ }^{5}$ The court in Abubakar Ahmed \& Anor. v. Crown Merchant Bank Limited' 6 applying the provision of section 410 CAMA 1990( now repealed) held that the following categories of persons have the right to bring petition for winding up of a company before the court, they are:

a. the company;

b. a creditor, including a contingent or prospective creditor of the company;

c. the official receiver;

d. a contributory;

e. a trustee in bankruptcy to , or a personal representative of a creditor or contributory;

f. the Commission under CAMA, 2020;

sections 635- 641 CAMA 2000 for the procedure for creditors' voluntarily winding up.

${ }^{1}$ See also generally section 621-624 CAMA 2020

${ }^{2}$ Section 620 (1) CAMA 2020

${ }^{3}$ Section 625 CAMA 2021

${ }^{4}$ See also generally section 621-624 CAMA 2020

${ }^{5}$ Akomolede, I. 2008. Fundamentals of Nigerian company law, Lagos, Niyak Print and Publications: 138. See generally the provisions of sections 635- 641 CAMA 2002 for the procedure for creditors' voluntarily winding up.

${ }^{6}$ (2006) All FWLR pt. 295: 695-696 paras. E-B 
g. a receiver if authorized by the instrument under which he was appointed; or

h. by all or any of those parties, together or separately. ${ }^{1}$

\subsubsection{Winding Up Subject to the Supervision of the Court}

Where a company passes a resolution for voluntary winding up, the court may on petition order that the voluntary winding up shall continue but subject to such supervision of the court, and with such liberty for creditors, contributories, or others to apply to the court, and generally on such terms and conditions, as the court deems fit. ${ }^{2}$ The effect of this kind of petition for winding up is that it is deemed to be a petition for winding up by the court. ${ }^{3}$

\subsubsection{Key personnel in winding up process}

It is imperative for the purpose of our discourse to examine briefly the duties of key officers associated with winding up process. CAMA 2020 among other statutes provides for the appointment and functions of such officers.

\section{1) Official Receiver}

Section 582 CAMA 2020 provides that for the purpose of the Act and in so far as it relates to the winding up of companies by the court, an 'officials receiver' could be aptly defined as the deputy chief registrar of the federal high court or as officer designated for that purpose by the chief judge of the court.

To enable the official receiver effectively discharge his/her responsibilities, the statement of company's affairs has to be made available to such personnel. It is a vital requirement that such statement be submitted, and shall be verified by one or more of the persons who are at the relevant date, the directors and the secretary of the company.

Where application is made to the court for the purpose of appointing a receiver on behalf of the debenture holders or other creditors of a company being wound-up, the official receiver may be so appointed.

Section 584 (1) of CAMA 2020 provides that if a winding-up order is made, the official receiver shall as soon as practicable after receipt of the statement to be submitted under section 583 of this Act or where the court orders that no statement be submitted, as soon as practicable after the date of the order, submit a preliminary report to the court.

Similarly, the official receiver may, if he thinks fit, make further reports expressing the process of the company's formation and indicate if he believes the process was tainted with fraud or possibly such fraud was committed by any officer of the company since its formation and whether it is necessary to bring same to the knowledge of the court.

\section{2) Liquidator}

According to the black's law dictionary, ${ }^{4}$ liquidator is a person appointed to wind-up business affairs, especially by selling off its assets. To liquidate, simply means to determine the liabilities and distribute the assets of an entity, especially in bankruptcy or dissolution or to windup the affairs of a corporation business etc.

The court may appoint a liquidator or liquidators for the purpose of conducting the proceedings in winding up of a company and performing such duties in reference to it as the court may impose and where there is a vacancy, the official receiver shall by virtue of his office, act as liquidator until such time the vacancy is filled.

It is important to note that upon the filing of petition for winding up but before the order is granted, the appointment shall be provisional and the court making such appointment may limit and restrict the powers of liquidator, exercising his discretionary powers. ${ }^{5}$

Orojo, in his book opines that the central figure in the winding-up of the company is the liquidator and so he must be appointed as soon as possible. The first meeting of the creditors and contributories respectively will decide whether the official receiver should continue to be the liquidator or another person should be appointed. ${ }^{6}$

The role of a liquidator in winding up process cannot in any way be over-emphasized, as stated earlier, liquidator is so central to the process that CAMA provides that there should be no vacuum, as such the position should always be filled. Section 585 (3) CAMA provides as follows: In the application of this section-

a) if a provisional liquidator is to be appointed before the making of a winding-up order, the official receiver, or any other fit person,

\footnotetext{
${ }^{1}$ Section 573 CAMA 2020 is the current law in force

${ }^{2}$ Section 649 CAMA 2020

${ }^{3}$ Sections 650 \& 651 CAMA 2020

${ }^{4}$ Ibid. $8^{\text {th }}$ edition, 950

${ }^{5}$ Section 585 (1) \& (2) CAMA 2020

${ }^{6}$ Orojo, J.O., (2006) Company law and practice in Nigeria, vol. 1 Commentary, Durban, LexisNexis Butterworths,: 542.
} 
may be so appointed;

b) on the making of winding up order, if no liquidator is appointed, the official receiver shall by virtue of his office become the liquidator;

c) The official receiver in his capacity as provisional liquidator shall, and in any other case may, summon meetings or creditors and contributories of the company to be held separately for the purpose of determining whether or not an application is to be made to the court for appointing a liquidator in place of the official receiver.

The Act further provides that more than one liquidator may be appointed by the court depending on the circumstance. One or more of such appointed liquidators may carry out duties so authorized by the Act as may be ordered by the court ${ }^{1}$

In a winding up by the court, the liquidator shall take into his custody, or under his control, all the property and chooses in action to which the company is or appears to be entitled. ${ }^{2}$

Similarly, where a company is being wound up by the court, the court may, on the application of the liquidator, by order direct that all or any part of the property of whatsoever description belonging to the company or held by trustees on its behalf shall vest in the liquidator by his official name ${ }^{3}$

The court in Nigeria Deposit Insurance Corporation (Provisional Liquidator of Progress Bank of Nig.Ltd.) v. Obende ${ }^{4}$ elucidate more on the purpose of appointing liquidator as follows:

The purpose of appointing a liquidator for a company

is not to conduct legal proceedings in winding up of

a company. That would be a very restricted function and one which would be rather unproductive in the interest

of all concerned. The real purpose of appointing liquidator is

for the liquidator to-

a. take control of the company

b. collect it assets

c. pay its debt; and

d. distribute any surplus among the member in accordance with their rights.

The court further opined that the aforesaid is what amounts to "conducting the proceedings in winding-up a company" and performing such duties in reference thereto as the court may impose as prescribed in the CAMA.

In Tony-Anthony Holdings Limited v. C.B. $A^{5}$ the court, inter-alia extends the role of a liquidator to include settlement of disputes among the stakeholders. The Act provides for persons who are disqualified from being appointed as liquidators of a company as follows:

The following persons shall not be competent to be appointed or to act as liquidator of a company, whether in a winding-up by, or under the supervision of the court, or in a

voluntary winding up

a. an infant;

b. anyone found by court to be of unsound mind

c. a body corporate

d. an undischarged bankrupt;

e. any director of the company under liquidation;

f. any person convicted of any offence involving fraud, dishonestly, official corruption or moral turpitude and in respect of whom there is a subsisting

order under section 672 and 280 of this Act. ${ }^{6}$

Any irregular appointment that runs contrary to the provision of law under references shall be void-ab-initio while such disqualified person named in subsection (1) (c)- (f) so 'appointed' shall be liable to a fine as prescribed by the Commission in the regulations in the case of a body corporate, in the case of an individual, to imprisonment for a term not exceeding six months or to a fine as the court deems fit or both. ${ }^{7}$

\footnotetext{
${ }^{1}$ See section 585 (4) CAMA 2020.

2 Section 586 CAMA.

${ }^{3}$ Section 587 CAMA.

${ }^{4}$ (2000) F.W.L.R pt.26 at 1874,paras. E-H. See also Solomon Abekhe v. Nigeria Deposit Insurance Corporation (1995) 7 NWLR pt. $406: 228$

5 (2013) All FWLR pt.698:944 at 969-970 paras C-B

${ }^{6}$ Section 676(1) CAMA 2020

${ }^{7}$ Section (2) CAMA 2020
} 


\section{SPECIAL MANAGER}

The law provides for the appointment of a special manager where necessary. Section 599 provides for the appointment of special manager as follows:

Where the official receiver becomes the liquidator of a company,

whether provisionally or otherwise, he may, if satisfied that the nature

of the estate or business of the company, interests of the creditors or contributories generally, require the appointment of a special manager

of the estate or business of the company other than himself, apply to the court for an order appointing a special manager to act during such time as the court may direct, with the powers, including those of a receiver or manager, as may be entrusted to him by the court and the court may make any order necessary.

\section{Effect of winding up order}

Winding-up order does not take -away the existence of the company completely, the company continues to exist as corporate entity till its dissolution. ${ }^{1}$ It is important to note that all the ongoing business of the company is administered by the liquidator during the phase of liquidation. The winding-up order operates as notice terminating the employment contracts of all the company's employees, who are thereby automatically dismissed. ${ }^{2}$ In Nigeria, the common practice is that the liquidators usually leave no stone unturned in a bid to ensure that the company's assets are harnessed and distributed to creditors and members in the statutory order of priority. Once the liquidator completes his duty as earlier noted, the company will usually be dissolved as the final phase of his task.

\section{Company's dissolution}

When the affairs of the company have been fully wound-up and liquidator makes an application in that behalf, the court must order the dissolution of the company.

It is noteworthy that where a company is dissolved, all property and right whatsoever vested in or held on trust for the company immediately before its dissolution, including leasehold property (but not including property held by the company on trust for any other person) shall, subject and without prejudice to any order which may at any time be made by the court under section 691 or 692 of this Act, be deemed to be vested in the state without further assurance, as bona vacanta.

However, even where a company has been dissolved, the court may, at any time within two years of the date of the dissolution, on an application being made for the purpose by the liquidator of the company or by any other person who appears to the court to be interested, make order, upon such terms as the court may be deem fit, declaring the dissolution to have been void, and thereupon such proceedings may be taken as might have been taken if the company had not been dissolved. ${ }^{3}$

When a company is dissolved, it ceases to be in existence, the employees lose their jobs, the government loses revenue from company's income tax and other taxable incomes, the private sector become less vibrant and contributes little to the nation's economy growth, just to mention a little of the attendant consequences.

In view of the adverse effects of dissolution of companies on the overall growth of the economy, it becomes imperative that attention be paid to a mechanism that seeks to revive or resuscitate the ailing company, other than the winding up proceedings/ dissolution that finally puts to an end the existence of a company.

There are many instances, where 'ailing' companies can still become healthy and contribute to the economic growth of a nation, without any prejudice to the interests of creditors, members and other stakeholders. The mechanism developed for this is called, "Corporate Rescue."

\section{Corporate Rescue}

This is a concept in company law and practice that has no universally accepted definition. It is however described as a 'sub-theme of insolvency law'. It is a process by which a distressed business may be resuscitated or rejuvenated, with or without its company.

Professor Belcher defined the term 'corporate rescue' as a major intervention necessary to avert eventual failure of a company. This involves any fundamental remedial action to a company at a period of corporate crisis, which include both the formal and informal strategic rescue mechanisms. ${ }^{4}$ This concept aptly seeks to give a

\footnotetext{
${ }^{1}$ See the following cases: C.C.B. Plc. v. Mbakwe (2000) FWLR pt . 14: 2351 at 2354 paras. D-E (A company wound-up or under a winding up proceeding is not dead, it is alive but sick. A company dies on its dissolution. C.C.B. (Nig) Ltd.v. Onwechekwa (2000) 3 NWLR pt. 647: 65

${ }^{2}$ Re Oriental Bank Corporation, MacDowall's Case (1886) 23 Ch. D. 366.

${ }^{3}$ See section 691 (1) CAMA 2021

${ }^{4}$ Belcher, A. (2009) Corporate Rescue , $2^{\text {nd }}$ edition London, Sweet \& Maxwell :12
} 
form of lifeline to a financially distressed company, so that instead of opting for the traditional or more conventional approach of company's liquidation, efforts are geared towards reviving the said ailing company.

Literally, company rescue refers to the preservation of the corporate entity, or some part of it, after distress has been remedied. Belcher highlights the impossibility of saving the entity intact. ${ }^{1}$ As earlier noted, the process is usually without prejudice to the interests and stakes of some pre-distressed stakeholder.

The preservation of the company, not just its business is fundamental to this notion of rescue. However, it is possible to sell the business of a distressing company to the existing owners, while the 'shell' is liquidated. This activity or action will not rob the company of the advantages associated with company rescue.

In summary, corporate rescue is a process by which a distressed business, including or excluding its corporates shell, may be salvaged and rejuvenated by a section of its existing owners when a piece-meal or market sale is either undesirable or impossible. However, for clarity purpose, the distinction between corporate rescue and business sales must be clearly highlighted. While corporate rescue works towards the restoration of a company in difficulty, which leads to the preservation of the legal entity itself so that the company can continue operations after reorganization, the business rescue implies the termination of the old company (the shell) but the core business and its activities will remain intact and thriving unit under a new leadership.

The aforesaid happens where a company is indeed insolvent but pragmatics steps are taken to retain the business as an operational enterprise so as to continue to buoy the private sector in particular, and overall economic activities continue. ${ }^{2}$

\section{Essential Elements of Corporate Rescue}

Three basic elements of corporate rescue has been identified, there are however many other ancillary issues which usually come up for determination during the process. The basic three essentials which shall be discussed seriatim are: (i) the rescue decision (ii) the rescue finance and (iii) the rescue plan.

\section{Rescue Decision-}

In the recent century, reorganization practice and modern management supports the position that the primal element of rescue is the decision on the desirability of preserving the company and/ or its business rather than liquidation and eventual dissolution.

Finance theory also supports the notion that creditors must take a decision on business at default. The person or group of persons who should take such decision depends on the stakeholders in the company and interests being represented. A fundamental factor to be considered however is that such decision has to be taken without bias or sentiment.

What is obvious is that the law cannot force parties to rescue distressed companies; neither can it be structured to predict the viability of businesses. It merely provides a framework that facilitates the decisionmaking process. The parties decide the outcomes.

It is of importance that the law is structured to ensure that the representatives of all tiers of investors are consulted at the negotiations, because it just appears unclear who the actual residual claimant is.

According to Lopucki \& Whitford in their survey of re-organization cases, the parties which are absent at the negotiation table usually receive nothing. ${ }^{3}$

\section{Rescue Finance}

Rescue finance means financing provided to the company or any of its subsidiaries, which financing is reasonably required to: (i) remedy a breach or default by the company or any of its subsidiaries under any debt financing agreements to which the company or any of its subsidiaries are party; (ii) provides liquidity to the company or any of its subsidiaries to the extent necessary to fund their then-current operations, under circumstances where the failure to provide such liquidity would reasonably be expected to be materially adverse to the company, or (iii) comply with applicable capital requirements laws, rules or regulations. ${ }^{4}$

In the $21^{\text {st }}$ century, one of the fundamental issues being grappled with was the creation of a profitable capital; structure for the company within which the rescued business was to operate. Similarly, a group of turnaround specialists have identified the first financial problem to be resolved by distressed companies as that of initial cash flow, if the business is to be established or survive. ${ }^{5}$

Reorganizing business may also include refinancing with a view to promote future growth. It is therefore

\footnotetext{
${ }^{1}$ Ibid. Belcher, A.

${ }^{2}$ Finch, v. (2009) corporate Insolvency Law: perspectives and principles, $2^{\text {nd }}$ edition, Cambridge, cup : 188

${ }^{3}$ Lopucki, L. \& Whitford, W.(1991)Bargaining over Equity is share in the Bankruptcy Reorganization of large and publicly held companies. 39 Unipenn LR: 125

${ }^{4}$ Rescue financing definition. Retrieved Sept. 15, 2021 from law insider. Com/ dictionary

${ }^{5}$ Blayney, M. 'Funding a Business Turnaround - 5 steps to success' Retrieved Sept. 15, 2021 from http://www.tmauk .org/uploads/funding \% 20a \% 20 Business \% 20 Turnaround \% $201 \% 20$ to \% 205.
} 
safe to conclude that if rescue is to be achieved; both short and long-term finance problems face by the distressed company must be resolved.

It is noteworthy that decision must be made on how to facilitate the provision of short term finance. Empiricists find that companies with access to short- term funds are likely to be re- organized successfully; or at least, the fates of such companies are determined in less time than it takes companies without short-term finance. ${ }^{1}$

When the business or company has been stabilized, it becomes imperative to relieve the company of some of its debt load going forward. However, this requires negotiations among the pre-distress claimants. The proposed financial restructuring plan may be rejected by the claimants, though it is the best possible in the circumstances.

Sometimes, some parties may resolve to hold-out or enforce the nuisance value of their claims; in a bid to obtain pay-outs during the negotiations.

However, where a proposed plan is rejected, liquidation would be the only other option, unless the system provides for the presentation of a subsequent proposal which would not be guaranteed approval either.

In the alternative, the party who proposed the plan should be permitted to pray the court to uphold the proposed rejected plan. The court in turn may examine the plan to determine the fairness to the stakeholders, particularly if the stakeholders will at least receive the liquidation values of their claims. The court will thereafter exercise its discretion based on the facts presented before it.

\section{The Rescue Plan}

Decision to rescue an ailing company must be taken at some point and the plan to implement this decision involves proceeding which aimed at facilitating the rehabilitation of the going-concern in distress by providing for the following-

i. The temporary supervision of the company, and the management of its affairs, business and property, by a business rescue practitioner.

ii. A temporary moratorium (stay) on the rights of claimants against the company or in respect of property in its possession; and

iii. The development and implementation, if approved, of a business rescue plan to rescue the company by restricting its business, property, debt, affairs, other liabilities and equities. ${ }^{2}$

The aim of a rescue plan is to restructure the affairs of a company in such a way that either maximizes the likelihood of the company continuing in existence on a solvent basis or results in a better return for the creditors of the company that would ordinarily result from the liquidation of the company.

In a recent decision of the South Gauteng High Court, in the case of Welman v. Marcelle Props ${ }^{3}$ the court held as follows:

\section{Business rescue proceedings are not for terminally ill close corporations. Nor are they for chronically ill. They are for ailing corporations, which given time will be rescued and become solvent.}

This ratio of the court supports the contention that at the first signs of financial distress, a company or better still, the concerned stakeholders should plan how to rescue such company and / or its business.

It is important that the plan indicates just how the rescue decision was made. Similarly, the plan should clearly outline the changes that would be made to the company's or business operations to ensure that it is indeed rescued. Similarly, as part of the rescue plan, it may be necessary to retain some pre-distressed managers, particularly where small companies are involved, as their 'firm- specific' knowledge may be vital to the rescue. The three major elements/ components of corporate rescue discussed above form the core procedure for corporate rescue.

The benefits of Corporate Rescue-

The benefits of corporate or business rescue far outweigh its seemingly demerits. Some of these benefits are highlighted below:

i. Business Rescue may provide a better return for creditors. This is one of the core advantages of corporate rescue. If the rescue is successful, the likelihood of creditors making huge return on any outstanding debts is higher than when such company goes through insolvency proceedings. This could be as a result of improved return upon the realization of effective company asset utilization

\footnotetext{
${ }^{1}$ Carpet, M. (2003). Does Debtors- in- possession Financing Add value? Cass Business School:1. Ayotte, k. \& Morrison, E. (2009). Creditor control and conflict in chapter 11 Bankruptcy. Journal of Legal Analysis: 511

${ }^{2}$ Werkmans- Basics- of- Business-Rescue (2011.) Retrieved Sept. 15, 2021 from www.werkmans.com

${ }^{3} 193$ CC JDR (South Africa)
} 
and having to cut-off the enormous cost of liquidation which include the liquidator's fee.

ii. It may help the company achieve solvency, particularly where in the course of rescue plan and negotiations, the creditors agree to write-off part of the company's debt. Though, this on a shortterm will result in loss of income to the creditors but on the long-term, with continued patronages, it will be beneficial as well to the creditors.

iii. A rescue company is preferable to a liquidated company. This is no doubt one of the greatest potential benefits of corporate or business rescue. There is a great and immeasurable contribution a rescued company can provide. Its continued existence guarantee added value to the economy of the nation of its place of operation, in terms of tax payable to the taxing authorities.

iv. Preservation of employees and assets

The economic climate and employment opportunities in the $21^{\text {st }}$ century leaves more to be desired (they are in parlous state) hence a successful business rescue will check the growing unemployment rate and its attendant adverse consequences.

Although it has been argued that corporate or business rescue are usually not viable, however the numerous negatives associated with liquidation and disillusion make it less attractive.

Corporate Rescue: The Nigeria Perspective-

Nigeria is not exempted from a number of developing countries which has been experiencing decline in the fortunes of her companies/corporate organizations, which was a resultant effect of quite a number of factors, ranging from inflation/mis-management of the economy, corruption to the recent widespread pandemic of covid19. Corporate rescue is a new concept in Nigeria company law and practice, hence the dearth of literature in this area of law. revival.

The previous insolvency law and practice regime focuses more on company's liquidation than company's

The closest to the concept of corporate/business rescue is the principle which underlies mergers and acquisition.

Idigbe and Kalu, justify the above assertion in their work; which examined the scope of the modern reforms on the law of insolvency, with particular reference to the 2015 AMCON Act (amended). According to the authors, the original AMCON Act (i.e No.4 of 2010) sought to apply business rescue mechanism that would aid separation of the failed aspect of banking business from the virile portion and therefore create a third party institution to manage the ailing portion thereof without necessarily tempering with the employees' status. At the same time while having as its target the need to improve the liquidity and business activities of the bank as much as possible. This method is in contrast to the Central Bank of Nigeria (CBN) and the Nigerian Deposit Insurance Corporation (NDIC) which favour take-over of management and eventual liquidation of the ailing company. ${ }^{1}$ Major economies of the world, such as the United States of America, Britain, Germany, Australia and France have realized that there are numerous advantages from rescuing ailing companies or the business activities, particularly where such going-concerns have potential to survive the ailment. The efforts have cumulated in formal introduction of the specific legislations for business rescue.

It is no longer in doubt that an ideal insolvency regime is the one that gives room for not just the survival but also the continued viability of ailing companies. Similarly, it ensures that a failing business with a very low possibility of recovery have hitch- free and flexible liquidation that allows the capital generated from the proceeds of the assets to be re-invested in another viable business.

The CAMA 2020, in line with global best practices offers an insolvent company an opportunity to continue as a going-concern. ${ }^{2}$ CAMA 2020 reflects quite a number of commendable amendments and introduces new provisions that conform to global best practices in the area of insolvency law and practice.

The highlights of the new insolvency provisions are as follows:

i. Administration and Company Voluntary Arrangement

This option provides avenue for business rescue options to first be prioritized and explored before receivership and involuntary liquidation. Section 710 CAMA 2020 defines the word, 'arrangement' to mean 'any change in the rights or liabilities of members, debenture holders or creditors of a company or any class of them or in the regulation of a company, other than a change effected under any other provision of the Act or by the unanimous agreement of all parties affected.'

The Act further provides as follows:

1. Where under a scheme proposed for a compromise, arrangement or reconstruction between two or more companies or the merger of any two or more companies, the whole or any part of the undertakings

\footnotetext{
1 Idigbe, A \& Kalu,O. Recent strides in Nigerian Insolvency Law and AMCON Act, in Yebisi, E.T \& Omidoyin, T.J. (2018) Journal of Law, policy and Globalization, vol.43:46

${ }^{2}$ Strachan Partners (2020) Review of the companies and Allied Matters Act 2020 : Company Rescue Mechanisms-Retrieved Sept. 20,2021 from strachanpartners.com uploads (PDF) 014
} 
or the property of any company concerned in the scheme in this section referred to as " the transfer of company" is to be transferred to another company, the court may, on the application in summary of any of the companies to be affected, order separate meetings of the companies to be summoned in such manners as the court may direct. ${ }^{l}$

The Act explains the procedure further that where a majority representing the minimum of $3 / 4$ (three-quarter) in value of the shares of members voting at each of the separate meetings, agree to the scheme, upon an application to the court by one or more of the companies, the Court exercising its power shall sanction the scheme. ${ }^{2}$ When the scheme is sanctioned by the court, the effect is that it becomes binding on the companies. ${ }^{3}$

ii. Administration is also recommended for ailing companies or companies that are at the point of being financially distressed. The objectives of administration primarily are ;

(a) rescue the company, the whole or any part of its undertaking as a going-concern;

(b) to achieve a better result for the company's creditors as a whole than would be likely, if the company were wound up, without first being in administration; and

(c) to realise property in order to make a distribution to one or more secured or preferential creditors. One major positive effect of the administration is that where a company is under such regime or phase, a resolution cannot be passed for the winding up of the company. In the same vein, neither can an order be made for winding-up of the company, except on the grounds of public interest, or where the application for winding up is made for regulated entities in the financial industry. ${ }^{4}$

Similarly, the moratorium during administration indicates that where a company is in administration, enforcement steps, legal proceedings, execution, distress, exercise of the right of peaceable re-entry amongst others may not be commenced or instituted against the company without the consent of the administration or permission of the court as the case maybe.

iii. Another notable provision is section 665 CAMA which provides inter-alia for the continue supply and employment of essential contracts to the companies undergoing insolvency. Such essential services include supply of water, electricity and gas in spite of their financially challenging situation. By specifically permitting the supply of these essential services in any of the insolvency options, the new insolvency regime seeks to ensure that the companies in financial distress are able to continue operations ultimately for the benefit of corporate/business rescue.

iv. Interestingly, the bench-mark or yardstick for determining a financially distressing company has now being increased under CAMA 2020. In a bid to classify a company as such that is unable to pay its debt, the previous amount of \#2,000(two thousand naira) has now been increased to a sum exceeding \#200,000 (two hundred thousand naira).

v. Also, for an unregistered company, such a company is deemed unable to pay its debts where such debt is in the sum of \#100,000(one hundred thousand naira), contrary to a sum of \#100(one hundred naira) fixed in the repealed CAMA. It is believed that it will be easy to identify a distressing company early enough and apply business rescue option before the case becomes irredeemable.

vi. Notably, a laudable innovation in the CAMA 2002 that seeks to elevate the insolvency regime in Nigeria to the level of global standard practice is the provision for insolvency pr actioners, which is a deliberate attempt at regulating the practice.

The Act spelt out among other things, the class of people to act as insolvency practitioners (IP), qualification of insolvency practitioner and the process of being recognized and authorized to act as IP. ${ }^{5}$

\section{Conclusion}

A careful analysis of the global best practices of insolvency law and practice reveals that more than ever before there is a dire need for adequate legal framework for insolvency practice that will make its fulcrum or focal point corporate/business rescue.

Rescuing ailing or financially distressing companies will go a long way to ensure healthy and vibrant economies where large scale unemployment will be obliterated and improved standard of living enthroned.

The unfortunate incident of covid-19 pandemic with its attendant consequences of economic woes more than ever before has geared up stakeholders and regulators in the area of company law and practice towards deploying corporate or business rescue mechanism for strengthening companies and ultimately builds a virile private sector

\footnotetext{
${ }^{1}$ See section 711 (1) CAMA 2020

2 Section 711 (2) CAMA 2020

${ }^{3}$ See section 711(3) CAMA 2020

${ }^{4}$ Orewale, O., Momodu, P., Atewologun, O. and Okoye, O. (2020) Fostering business rescue- the new insolvency regime in CAMA 2020

Retrieved Sept. 20, 2021 from legal.businessday.ng

${ }^{5}$ See generally sections 704-709 CAMA 2020 (chapter 26- miscellaneous provisions applying to companies which are insolvent).
} 
For Nigeria to move forward economically, its policies and laws on company law and practice must be designed to conform with the global best practices which makes insolvency law more progressive by focusing on reviving distressing company rather than winding it up at the earliest opportunity.

Similarly, the judicial process regarding company law and practice in Nigeria should be structured in in a way that the survival of the business rather than its collapse and eventual dissolution should be attractive and encouraged.

Finally, it is suggested that a robust and separate comprehensive legislation on Insolvency, with much emphasis on Corporate Rescue be put in place since the relevant provisions in CAMA and ISA (Investment and Securities Act) are inadequate.

\section{REFERENCES}

Akomolede, I. (2008) Fundamentals of Nigerian Company Law. Lagos, Niyak Print and publications Belcher, A. (2009) Corporate Rescue, $2^{\text {nd }}$ edition, London, Sweet and Maxwell

Finch, V. (2009) Corporate Insolvency Law: prospective and principles, $2^{\text {nd }}$ edition, Cambridge, CUP.

Fletcher, I. \& Crabb, L. (1990) The law of insolvency, $4^{\text {th }}$ edition, London, Sweet \& Maxwell

Keenan, D. (1987) Smith and Keenan's Company Law, seventh edition, London. Pitman Publishing

Orojo, J. O. (2006) Company Law and Practice in Nigeria. Durban, Lexis Nexis, Butterworths

Sealy, L., Worthington, S. (2010) Sealy's cases and materials in company law, $9^{\text {th }}$ edition Oxford. Oxford University Press 